ISSN 0854-9818

CIFOR OCCASIONAL PAPER NO. 4

Mar 1995

\title{
Science and International Nature Conservation
}

Jeffrey A. Sayer

CENTER FOR INTERNATIONAL FORESTRY RESEARCH

office address: Jalan Gunung Batu 5 Bogor 16001 Indonesia

mailing address: P.O. Box 6596, JKPWB Jakarta 10065 Indonesia

tel.: +62(251) 34-3652 fax: +62(251) 32-6433

e-mail: cifor@cgnet.com 
Foundation 'Chair Prins Bernhard'

Founded in 1986 at occasion of the 75th birthday of H.R.H. Prince Bernhard

Department of Plant Ecology and Evolutionary Biology

P.O. Box 800.84

3508 TB Utrecht

phone: +313053683.5

fax: + 3130518366 .

e-mail: wimd@boev.biol.ruu.nl

Account number:

ABN-Amro Bank Heemstede rek. 49.82.95.559

Board of the Foundation:

Drs. G.H.J.M. Peijnenburg, Chairman

Jhr. mr. D.J.H.N. den Beer Poortugael, Vice-Chairman

Mr. M.M. Slingenberg, Secretary

Mr. W.J.C. Tensen, Treasurer

Jhr.mr. P.H.G. Nahuys

Mr. F.Th. Dijckmeester

N.F.Halbertsma

Prof.dr. J.A.R.A.M. van Hooff

Board of Governors

Prof. dr. M.J.A. Werger Chairman

Prof. dr. J.A.R.A.M. van Hooff Secretary

Dr.A.P.M. van der Zon

Jhr. Mr. D.J.H.N. den Beer Poortugael

Mr. W.J.C. Tensen 


\title{
Science and International Nature Conservation ${ }^{1}$
}

\author{
Jeffrey A. Sayer ${ }^{2}$
}

\begin{abstract}
Summary
International nature conservation programs were originally driven by field biologists. As environment has assumed increasing prominence on the international political agenda, the role of biologists has been marginalised. International programs now have ambitious targets set by politicians and aspire to save the world. There is a need to balance these global environmental initiatives with a set of shorterterm practical actions to maximise biodiversity conservation. Biological scientists can cooperate with other natural resource specialists and social scientists in defining more targeted cost-effective nature conservation programs. A case is made for the Prince Bernhard Chair at the University of UTRECHT to focus on this interface between science and conservation practices.
\end{abstract}

\section{Introduction}

Somebody once said that Universities should be centers of constructive subversion. I intend to use my inaugural lecture to make some mildly subversive remarks about international nature conservation. I am doing this because of the frustration that I feel with present international efforts to conserve nature. This frustration is shared by many people involved in conservation. It is certainly shared by His Royal Highness, Prince Bernhard. Last October, I discussed many of these issues with him and I believe that he would wish to see the activities of the Foundation Chair leading directly to improvements in practical conservation action on the ground. I am very sorry that His Royal Highness cannot be with us today and I am sure that you will all join with me in wishing him a rapid recovery.

One of the problems is that the conservation agenda is no longer set by conservation professionals. It is being set by activists, lobbyists and politicians. This means that it is susceptible to wild swings in political fortunes. Three years ago the election of the Clinton Administration in U.S.A. brought a strongly proenvironment team to the White House. But at the end of last year the American people elected a right wing congress. This congress no longer had to contend with its traditional enemy - The Russian Communists - so it needed a new enemy. It is choosing the environmental movement. In some North American circles environmentalists are now known as water melons; they are said to be green on the outside, but under the surface they are red. This environmental backlash was epitomised by a remark made by Margaret Thatcher 'when England went to war with Argentina over the Falkland Islands. She is reputed to have said that, "after all these years battling with environmentalists, it is nice to have a real crisis".

There is a real danger of this environmental backlash spreading to tropical developing countries. We can avoid this if we apply scientific rigour to the definition of conservation priorities and if we ensure that we set these priorities in their appropriate social, economic and political context. The role that I see for the Prince Bernhard Foundation Chair is in mobilising more science, from a range of disciplines, to help redefine the international conservation agenda.

This is not to say that I see conservation as the exclusive preserve of scientists. It is obviously good that many important international institutions have become interested in nature conservation. What is not so good is that economists and planners at organisations like the World Bank should take over the process of setting the world's conservation priorities.

Economists certainly have a role to play. The problem is that economists like to make predictions - one definition of an economist is that he is an expert who will know tomorrow why the things he predicted yesterday did not happen today. It has been said that God created economists because he wanted to make weather

\footnotetext{
I Inaugural lecture for the Prince Bernhard Chair at the University of Utrecht, Department of Plant Ecology and Evolutionary Biology, P.0.Box. 800.84, 3508 TB Utrecht, The Netherlands.

2 Director General, Center for International Forestry Research, P.0. Box. 6596, JKPWB, Jakarta 10065, Indonesia.
} 
forecasters look good. I have more serious doubts about the role of planners. A planner has been defined as somebody who knows 150 ways to make love but does not know anybody to make love to.

However, the real problem with placing nature conservation in the hands of big international bureaucracies is that conservation can only succeed if it is based on a thorough understanding of local ecological, social and economic conditions. Big international organisations are not good at this. They like simple standardised solutions to problems. There is a rhyme about the World Bank that says this nicely:

World Bank highest of them all

Looks down to see poor people small

Like atoms, all the same a size,

For which its right to standardise.

\section{Taking Stock: is nature conservation progressing?}

The 1992 Rio Summit of the United Nations Commission on Environment and Development was the largest gathering of heads of state in history. It focused strongly on forest conservation. Since Rio aid agencies have disbursed millions of dollars for forests; the latest replenishment of the Global Environment Facility was $\$ 2$ billion, much of it for forests and for biodiversity. We have an International Convention on Biodiversity signed by almost all nations, and other conventions and agreements dealing with the Tropical Timber Trade, Trade in Endangered Species, The World's Natural Heritage, etc. The world's Forest Ministers are meeting in Rome today to decide whether we should begin the protracted process of negotiating an international convention on forests.

One might expect, with so much support, money and effort, that we would be able to point to some concrete advances in securing the conservation of forest biodiversity. Surely after two decades of unprecedented political attention the advocates of international forest conservation might be able to claim some successes.

Unfortunately, the link between political action and the realities on the ground is not evident. One of the problems has been that the conservation community has had a negative agenda. It focuses on stopping things, or banning things. "Halting tropical deforestation" is a useful political slogan, but in order to achieve conservation it would be more useful to have targets for how much forest is needed, where it should be and what products and services we require from it. If we had this clear vision of where we are trying to go it would be much easier to know if we are getting there.

Conservation science is central to answering these questions. We need to apply the learning of several disciplines from the biological, physical and social sciences in a coherent way to understand which forests must be conserved and how this can be achieved. I believe that the University of Utrecht, amongst its diverse faculties, has the skills and knowledge to make major contributions in this area. The Prince Bernhard Chair of International Nature Conservation should be an interface between conservation science and conservation practice. I would like to use my tenure to try to harness some of this potential to improve the scientific basis of tropical nature conservation.

The purpose of this paper is to examine the ways in which science could help make nature conservation programs more effective. I am afraid that the failure of science to set the international nature conservation agenda has left a vacuum. This vacuum has been filled by people whose intentions are good but who have been primarily fund-raisers or activists. These people are enthusiasts. It was a British Prime Minister, Balfour, who said that, "it is unfortunate, considering that enthusiasm moves the world, that so few enthusiasts can be relied upon to tell the truth". These enthusiasts have not really understood the scientific basis of nature conservation in tropical developing countries. They have led us into programs that were destined to fail. My contention is that the primary problem is no longer to obtain more money for conservation, but to spend the money that we have more efficiently. The problem is not to raise more political awareness, but to deliver to our politicians solutions to the immediate needs of tropical nature conservation which are more rigorously argued, pragmatic and highly targeted.

The inefficient use of money available for conservation is incurring considerable opportunity costs. The cost is manifest in lost nature; in the extinction of species and the loss of valuable areas of natural habitats. These losses are, to a large degree, irreversible and they are occurring rapidly. Opportunities to save 
representative and unique examples of the world's major tropical ecosystems will decline over the next decade or so. We need to harness the human and financial resources available for nature conservation to the highest priority areas and species and to do so quickly.

\section{The European Experience}

In examining the efficiency of efforts to save nature in the tropics it is worth looking first at the way in which nature conservation programs have evolved in our own countries. In the U.K. scientific nature conservation was not initiated by government. It was begun by naturalists, a relatively small number of dedicated individuals who were concerned at the loss of species and habitats. They had very clear targets, to protect a small number of localities where rare species, unusual habitats or representative assemblages of species occurred. The success or failure of their efforts was easy to assess. The status of the species and ecosystems could be readily monitored. To achieve their objectives conservationists acquired land and provided physical protection. It was only subsequently that governments became major actors in nature conservation.

Government involvement was first needed to provide legal support for the work of the NGOs. Subsequently, it helped expand systems of nature reserves to include sites that were beyond the means of the non-governmental sector. The latter point is important. Private conservation organisations have to weigh carefully the costs and benefits of their programs. In order to maintain the interest and support of their members they must focus on areas or species which their members perceive to be valuable. By making choices between sites and between different methods of conservation, they act in accordance with classic economic principles and ascribe different values to different sites or species. This is not happening in modern programs in the tropics. Vast amounts of money are being invested in sites whose natural values are not proven. Other sites known to be of high value are being neglected.

In transferring our attention to the tropics it is, of course, important to recognise that the starting points were quite different, economically, socially and ecologically. In the Northern European situation we were dealing with flora and fauna impoverished after the Pleistocene glaciations, a relatively affluent society occupying a large proportion of the land and well-developed legal arrangements for land ownership and transfer. In addition, our culture embodies a deep respect for the life of other species. This may not be shared by all cultures and may be particularly developed in the religions born in the species poor arid lands of the middle east. Indeed, given that most species of life on the planet are tropical forest arthropods, and that many of them specialise in decomposing timber, it would have been surprising if Noah, launching his ark in the moist regions of the tropics, would have found it attractive to include examples of all 30 million species of wood-eating beetles in his cargo. In the species-poor regions of the world it makes sense to try to conserve all species. In the species-rich forests of the humid tropics, the opportunity costs of conserving all species are too high and it is essential to establish priorities.

\section{The 1960s - A Decade of Progress for Conservation}

Nature conservation in the tropics took root in an environment where wild nature was still an abundant resource. Colonial regimes in Africa and Asia quickly recognised a few outstanding sites as being of global value for rare species and for species richness. Gunung Leuser and Ujung Kulon in Indonesia and the Virunga Mountains in Eastern Zaire are in this category. Most tropical countries began the post-colonial period with some protected areas, often quite well managed and usually subject to few conflicting demands, but they did not include the full range of ecological conditions or species in the countries concerned. The strong international focus on tropical forests is a recent development. Tropical rainforests were not a conservation priority until after 1965 (Fig. 1).

Virtually all of the National Parks in the humid lowland tropics have been established in the last 30 years. This can be attributed to the understanding of the species richness and ecological complexity of rainforests in the 1950s and 1960s.

The 1960s were, in my opinion, a period of great progress for nature conservation in the tropics. Much conservation legislation dates from this period. Many protected areas were established and the U.N. agencies, notably FAO and UNESCO, were active in promoting 


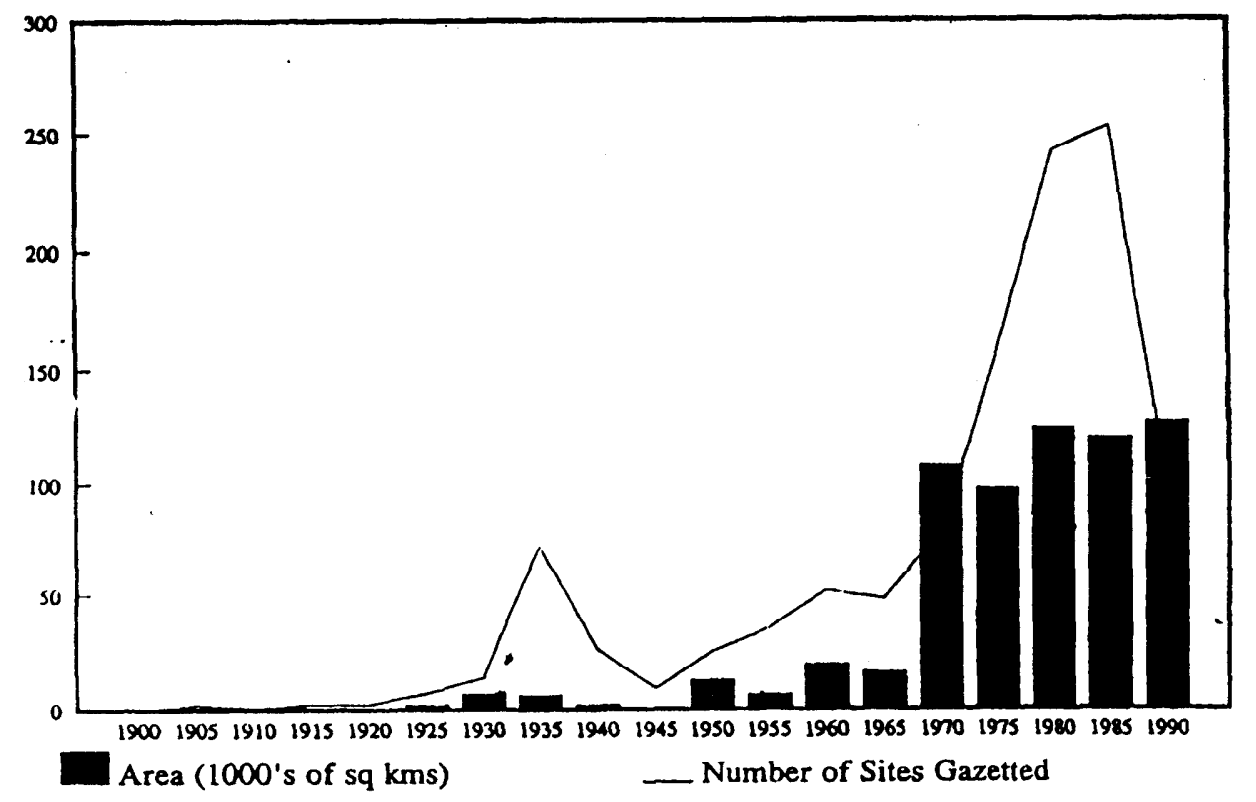

Figure 1. Protected Areas in Udvardy Tropical Forest Biome

conservation programs - much more so than they are today. It is difficult to monitor changes in nature conservation policies. One organisation that does provide statistics is the World Wide Fund for Nature. WWF is a large, diverse organisation and its policies are probably a reasonable reflection of the state of international conservation thinking. I have analysed the trends in the frequency of certain categories of WWF expenditures over recent decades to see what they tell us about changing perceptions of the world's conservation priorities (Fig. 2).

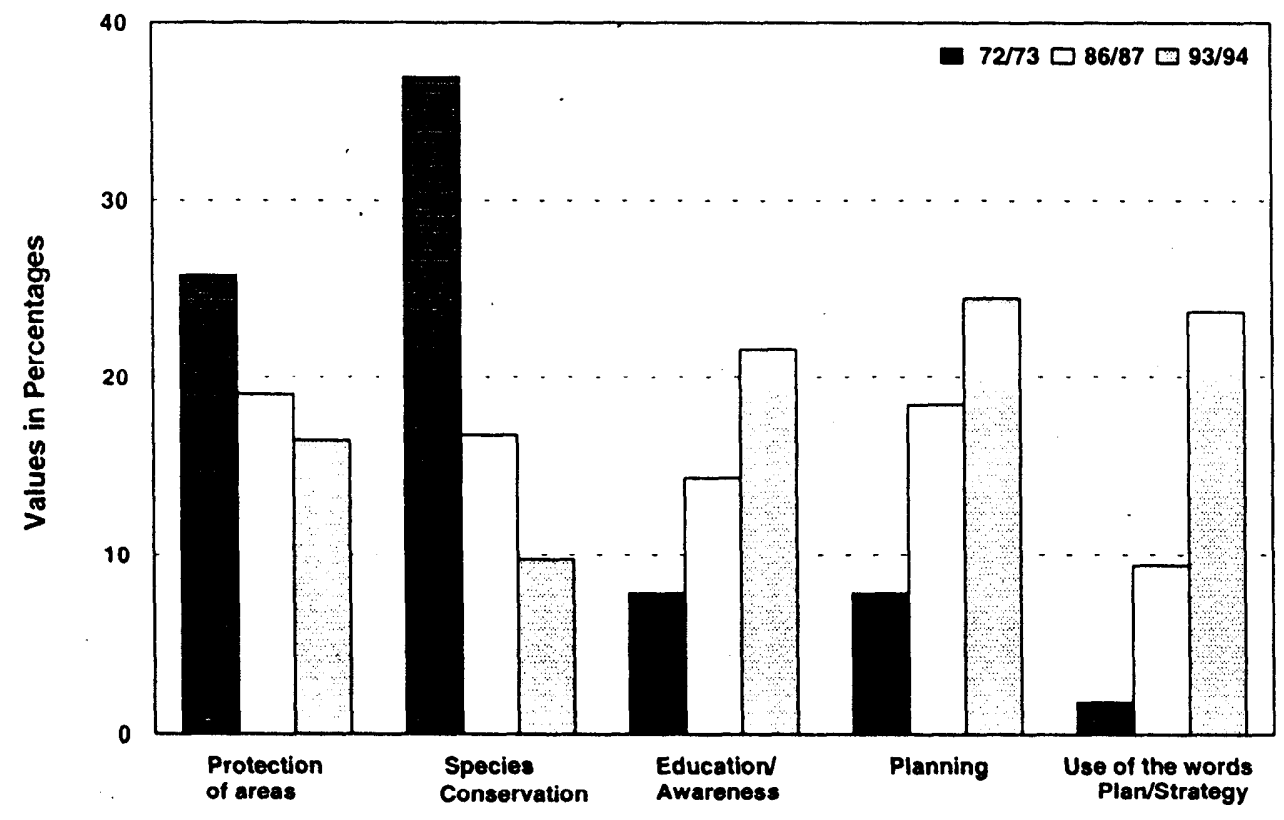

Figure 2. Changes in profile of WWF project objectives 1972-94 
In its early years WWF focused largely on practical conservation action. It was in the late $70 \mathrm{~s}$ and $80 \mathrm{~s}$ that it shifted towards conceptualising or planning conservation programs. Whereas in 1972/73 about 65\% of projects aimed at the conservation of a particular species or area, in 1993/94 only about $28 \%$ of projects had this focus. The words "plan" or "strategy" occurred in the title of $2 \%$ of all projects operating in 1972/73 as against about $25 \%$ in $1993 / 94$.

During the 1960s the conservation movement was led by professional ecologists or amateur naturalists. They had clear and precise ideas of what they were trying to conserve - in general, rare species or areas with an unusual or representative assemblage of species, or arcas under specific threat. Because they knew what they were trying to achieve, it was relatively easy to measure success. The community was tightly knit and united around the influential IUCN/WWF nexus, so the lessons from successful and unsuccessful approaches to conservation were rapidly diffused amongst a community of professional conservation practitioners. At this stage of its development the conservation movement was focused on protecting species in areas set aside for this purpose. National conservation agencies in tropical countries invested in developing the skills and resources needed to manage areas of land. Conservationists were not, at this stage, trying to change the course of development, but they were testing options for achieving conservation on the ground and then focusing these efforts on those methods that achieved the best results. This was a form of empirical research. The profession of conservation practitioner was emerging.

\section{The 1970s - The Environmental Bureaucrats Take Over}

However, all of this changed in 1972 with the UN Environment Conference in Stockholm. These changes affected the way conservation was organised and the way in which the conservation agenda was set. The Conference brought together political leaders and conservationists for the first time in a formal intergovernmental negotiating setting. It led to the establishment of UNEP and indirectly to many countries creating Ministries of the Environment. Conservation moved from being the passion of dedicated individuals to being the daily bread of professional bureaucrats, lawyers and diplomats. IUCN's first General Assembly after the Stockholm Conference was in Kinshasa in 1975 and carried the slogan "Conservation for Decision Makers" - a big change from earlier General Assemblies that focused on conservation for monkeys or elephants. Biologists amongst you may point out that this does not represent a significant change.

When Ho Chi Minh was asked what he thought about the French Revolution he is said to have replied that it was too soon to say. It may be too soon to pass judgement on the long-term impacts of Stockholm. There has certainly been an increase in resources for, and political commitment to, conservation. But there may also have been a weakening of conservation practice and of the line agencies responsible for conservation management. To some extent this may have been an inevitable consequence of the vastly increased pressures on nature in the tropics, driven by the population explosion and changing consumption patterns. However, I believe that there are other lessons to be drawn from the more recent history of nature conservation which will help us to target our efforts more effectively in the future.

The Stockholm Conference was driven by the same Malthusian world view that motivated the Club of Rome: that in a world of finite resources there was a fundamental conflict between economic growth and environmental conservation, and the environment could only be saved if the course of development could be altered. One result of this was that saving wild nature became less important than saving the world. Trying to conserve nature within a broad developmental context was replaced by an attempt to radically change the developmental context itself. There was an assumption that development and population growth were the problem, and the solution was to have 'less destructive and resource-demanding developmental pathways and to control population growth.

During the rest of the 1970s the nature conservation movement sought to redefine its role in this broader context of environment and development.

\section{The World Conservation Strategy - Conservationists Discover People}

This culminated in 1980 with the publication by IUCN, WWF and UNEP of the World 
Conservation Strategy (WCS). This contained a great deal of wisdom and articulated the case for nature conservation much better than many subsequent works. Its basic message was that conservation and development are compatible and indeed mutually supportive. It made the point that conservation cannot be achieved unless economic development occurs to alleviate poverty and allow for more efficient use of land and more employment in services and industry. It declared that development cannot be sustainable unless the resources upon which it depends are conserved. These arguments are, of course, true. However, the WCS glosses over the complexity of these relationships. The WCS and the conservation movement in the 1980s pretended that if only everybody behaved rationally and all resources were used efficiently, then everything would be fine and both conservation and development objectives would be met. In today's jargon conservation and development were portrayed as being a win/win situation. The problem with this view of conservation was that it overlooked the diversity of views of conservation and development amongst different sectors of society. It also greatly overestimated the extent to which environmental concerns could change fundamental economic processes and human behaviour. Even in Holland it takes strong laws or financial subsidies to make people behave in an environmentally friendly way. The idea that prophesies of future resource constraints or exhortations to protect pandas could change the development pathway of the Asian economic tigers was naive.

\section{The 1980s - The Decade of Plans and Strategies}

The objective of many people actively involved in international conservation in the late 70s and 80s was to attempt to generate political acceptance for this effort to change the course of development. It was believed, perhaps naively, that there was an optimal balance between conservation and development and that developing country governments would find it in their own best interests to follow this development pathway. These governments had only to include conservation in their strategies or plans, and he presto, it would happen. It was common during this period to see conservation organisations claiming success when a conservation objective appeared in a government approved plan. Thus, IUCN and others considered that the existence of a management plan constituted a criterion against which management quality of a protected area could be assessed. Many protected areas in the tropics have not just one but several management plans, each produced by successive international projects. Often there appears to be little relation between protection status on the ground and the existence of these plans. A recent article in Newsweek referred to the period of central planning in the economies of Eastern Europe as, "seventy-five lost years". Experience of corporate planning in the private sector has shown that its impact had been disappointing (Mintzberg 1994). In recent years planning in general, and central government planning in particular, have lost much of their credibility, yet in nature conservation and natural resource management the 1980s was a decade when a high proportion of conservation effort went into planning. Somebody said that, "planning is like a ritual rain dance, it has no effect on the weather. But planners think it does. Moreover, most of the advice related to planning is directed to improving the dancing and not the weather".

Government programs, at least in poorer countries, are very much influenced by aid agencies. Aid agencies also were seduced by this mania for planning and sent teams of planning experts to the tropics. The best national personnel have all been assigned as counterparts to the experts as have the counterpart budgets always required by aid agencies. All the money and best people are involved in writing plans or strategies and the persons responsible for managing the resources on the ground are marginalised. There are numerous tropical countries where nature now is hopelessly overplanned and under-protected. My own view is that excessive planning and strategising can destroy practical conservation programs just as surely as sugar rots your teeth.

The situation is even worse than this - a good plan or strategy should be based on a carefully conducted analysis of the relative costs and benefits of different courses of action. It should recognise and address the issue of choices and trade-offs. Most plans for nature conservation do not do this. They are wish lists, inventories of all the things that might be done if resources were unlimited and trade-offs with other sectors did not exist. The ability to focus on what is most important, urgent and feasible has been lost. Probability of success, or even criteria for measuring success, seem to have been 
ignored. Planning is a waste of time unless it is accompanied by research to test different options. Normally this testing comes through feedback from management practice. In the tropics this feedback has not occurred because little practical management was taking place. Many of the fundamental assumptions in our plans have therefore not been tested.

A medieval English monarch, in seeking to prove to his subjects the limitations of his powers, installed himself on the beach and commanded the tide to cease advancing. King Canute demonstrated that this was not possible. There are striking parallels with recent activities of conservation organisations. Conservationists have been sitting in ivory towers exhorting the world to conserve the environment in general but these exhortations were not based on the reality of what did or did not work on the ground.

\section{Eco-Development - Changing the Way People Live}

This view that conservation is about efficient use of resources and rational behaviour has been reflected at the local level by a shift of emphasis away from park and reserve protection per se to an emphasis on integrating conservation and development. This translated into projects to support buffer zones around parks and reserves. The principle behind buffer zones was that investing in certain types of "eco-development" around protected areas would diminish the need for local people to encroach upon or poach resources from the protected area itself. There was a proliferation of so-called buffer zone or "integrated conservation and development projects" (ICDPs) throughout the 1980s and early 90s. Recent publications (Sayer 1991, Wells and Brandon 1992) have seriously questioned the impact of these projects. They have shown that there is little evidence that any of these projects yielded tangible benefits for the natural areas that they set out to protect. Nor can they be shown to have produced development benefits for the populations concerned. Investment in buffer zones or ICDPs is another reflection of the fact that conservation programs are being driven by the philosophy that it is possible to change basic human behaviour by planning and persuasion.

One of the most important protected areas in Indonesia, the Kerinci Seblat Reserve in Sumatra, has a permanent population of over a quarter of a million people. The economy of Indonesia is growing at $7-8 \%$ per year and the inhabitants of Kerinci Seblat are riding the wave of an economic boom. Initial plans to conserve the area were based upon ICDP concepts that education and ecologically friendly technologies would move the people towards a development pathway that would be compatible with the maintenance of the natural values of the area. Several years of negotiations with local people and the administrators in the region have shown these assumptions to be false. It is now becoming clear that conserving nature in this vast area of forest will inevitably conflict with the short-term economic well-being of many of the people. The benefits of nature conservation will accrue largely to the global community, not to the local farmers. In these situations no conservation program will work without major investments in regulation or compensation.

I would argue that, at present, Indonesia is struggling to establish a protected area system that might have been viable in the 19th century but will not be viable in the 21st Century. There is a need for a much more rigorous allocation of priorities to focus on those areas that are genuinely necessary to maintain biodiversity and those areas where there is a reasonable prospect of success. I suspect that the optimal arrangement for Indonesia's longer-term future would be a much larger network of small reserves strategically placed to cover, key habitats and developed in such a way that their values are more readily accessible to the population of the country. Thus, the Ujung Kulon Reserve in Java is clearly of outstanding international importance. It is listed under the World Heritage Convention and contains species, notably the Javan Rhinoceros, which are probably found nowhere else. Ujung Kulon is located only I50 kilometres from the city of Jakarta with a population of over 10 million people. It could provide unequalled opportunities for sensitising this population to the values of nature. Yet at present it is almost inaccessible to the average Indonesian. One might speculate that investment to secure Ujung Kulon and to develop a visitor infrastructure might yield greater conservation benefits than attempting to reconcile the enormous developmental conflicts that exist in some of the huge, proposed protected areas on the outer islands. In Europe and North America relatively small protected areas accessible from major population centers played an invaluable role in generating public support for conservation programs. Few such areas exist in the tropics. With rapid increases in literacy and disposable 
incomes together with increased mobility, systems of small protected areas accessible from major populatio ncentres could play an exceedingly important role in building the foundations for conservation in the future.

\section{The 1990s - A Return to Realism}

The negotiations that accompanied the United Nations Summit on Conservation and Development in Rio de Janeiro in 1992, and the subsequent debates on the (conventions) on Biodiversity and the Statement of Principles on Forests, have been criticised for not leading to concrete results. However, these events can also be seen as another turning point in the history of conservation. The UNCED process has finally brought into the open the fact that different people, and especially people at different stages of development, have widely diverging expectations and tolerances of nature conservation. When the Ramsar Convention on Wetlands (1971), the Migratory Species Convention (1979), the Convention on Trade in Endangered Species (1973) and the World Heritage Convention (1972) were negotiated, the people around the table were those who already agreed on their basic objectives.

The UNCED agreements were negotiated in a United Nations forum. All countries were present, not just the ones that agreed but also the ones that had a different view of conservation. The UNCED process has, therefore, been of extreme importance in demonstrating that conservation, at least biodiversity conservation, is not a win-win situation. The way that Americans will finally decide to manage the forests of the Pacific Northwest will not be the same as the way the Malaysians manage the forests of Sarawak. The philosophy of the World Conservation Strategy that there is an optimal way to manage all natural resources and that education and development will lead us inexorably towards it has now been shown to be wrong. Views on how to manage forests and other resources will differ between different societies and will continue to change with time. One result of this is that advocates of nature conservation will have. to recognis ethat they will be in conflict with other resource users. They will have to design programs which are more cost-effective and define their priorities more precisely. The solution does not lie in trying to change the course of development and neither does it lie in the defence of every scrap of wild nature against any form of development. There has to be a balance between continued pressure to ensure that development does as little harm to the natural environment as possible, and a much more targeted practical effort to conserve as much biodiversity as possible.

\section{So We Must Ask Ourselves the Question How much Forest Do We Need and Why Do We Need It:}

There are four basic reasons to conserve forests; (1) Global climate benefits - principally carbon sequestration; (2) National economic benefits forest products; (3) Regional and local climate and watershed benefits - principally controlling run-off and erosion; (4) Biodiversity.

Clearly for carbon sequestration we need as much, forest as possible. However, the roles of forests as both source of atmospheric $\mathrm{CO}_{2}$ and as a sink are relatively minor, in the long term, compared with fossil fuel releases. Carbon sequestration provides one additional reason to conserve forests but it does not make much difference which type of forest or where, and I do not propose to discuss it further here.

Similarly, market forces will ensure a continued supply of those forest products that societies need and will substitute or abandon those that are not essential. I will only consider this further insofar as some production forests are also valuable for biodiversity.

Watershed benefits have been a major argument for conserving large areas of upland forests. These arguments have ignored compelling evidence that the relationship between forest cover and water yield is complex, and the evidence does not support the view that forest cover should necessarily be maximised for watershed protection purposes. (Hamilton 1986, Cassells et al.1987). Figure 3 shows the variation on water flow in the Ping River in Northern Thailand during a period of intense deforestation. There is no apparent correlation (from Enters, in press). One cannot assume that watershed arguments will necessarily or always support the case for natural forest conservation.

\section{Focusing on Tropical Biodiversity}

Many initiatives to conserve tropical forests have failed to distinguish between the strategies needed to address these different conservation 

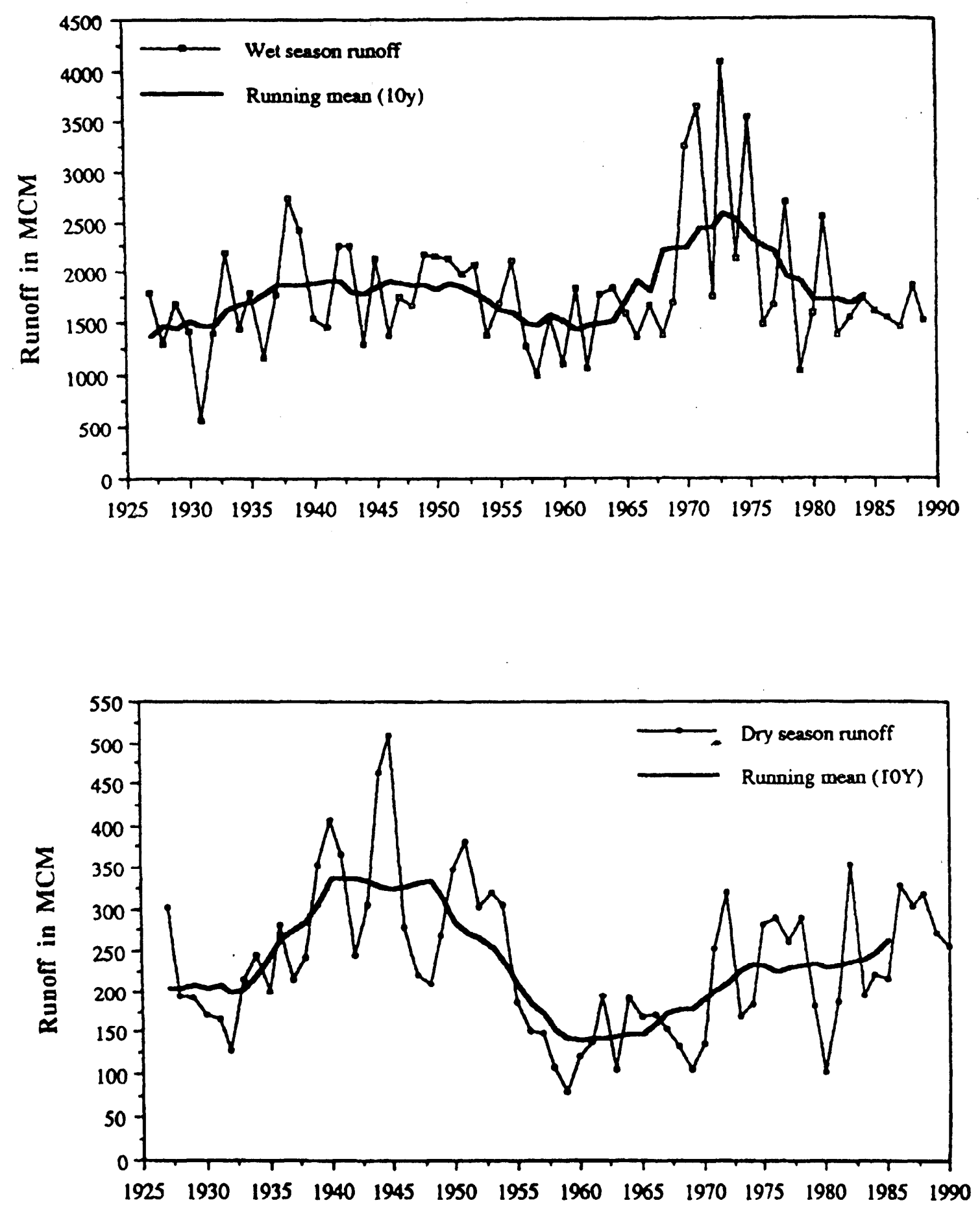

Figure 3. (a) Wet-Season Water Yield (b) Dry-Season Water Yield of Ping River as measured at Nawarat Bridge, Chiang Mai, between 1927-1990 (data from the Royal Irrigation Department). 
objectives. It has been assumed that biological diversity and ecosystem function needs are the same. Instead of starting with an analysis of conservation need and identifying locations and management regimes to meet this need, the starting point has usually been a survey of existing areas of intact forest. The different conservation arguments have then been marshalled to rationalise post-hoc the conservation of the biggest forests. In many countries these areas were in remote regions, often on the periphery of the country (Laos, Indonesia, Congo), and in a surprising number of countries, in areas occupied by minority or dissident groups (Thailand, Burma, Peru) or even by groups involved in illegal drug cultivation (Colombia, Thailand). In pursuit of their conservation objective, relatively weak conservation agencies found themselves confronted with major social and political, even military, conflicts. They clearly could not meet the challenge and have therefore often been discredited and marginalised. It is a basic rule of management that organisations should not set themselves targets which guarantee failure. But in many cases this is precisely what conservation agencies have done.

Figure 4 shows that most new protected areas have been established over the last 10 years in areas with the most extensive forests and many fewer in the most threatened forests. If the real motivation and focus had been biodiversity conservation one might have expected the opposite pattern.

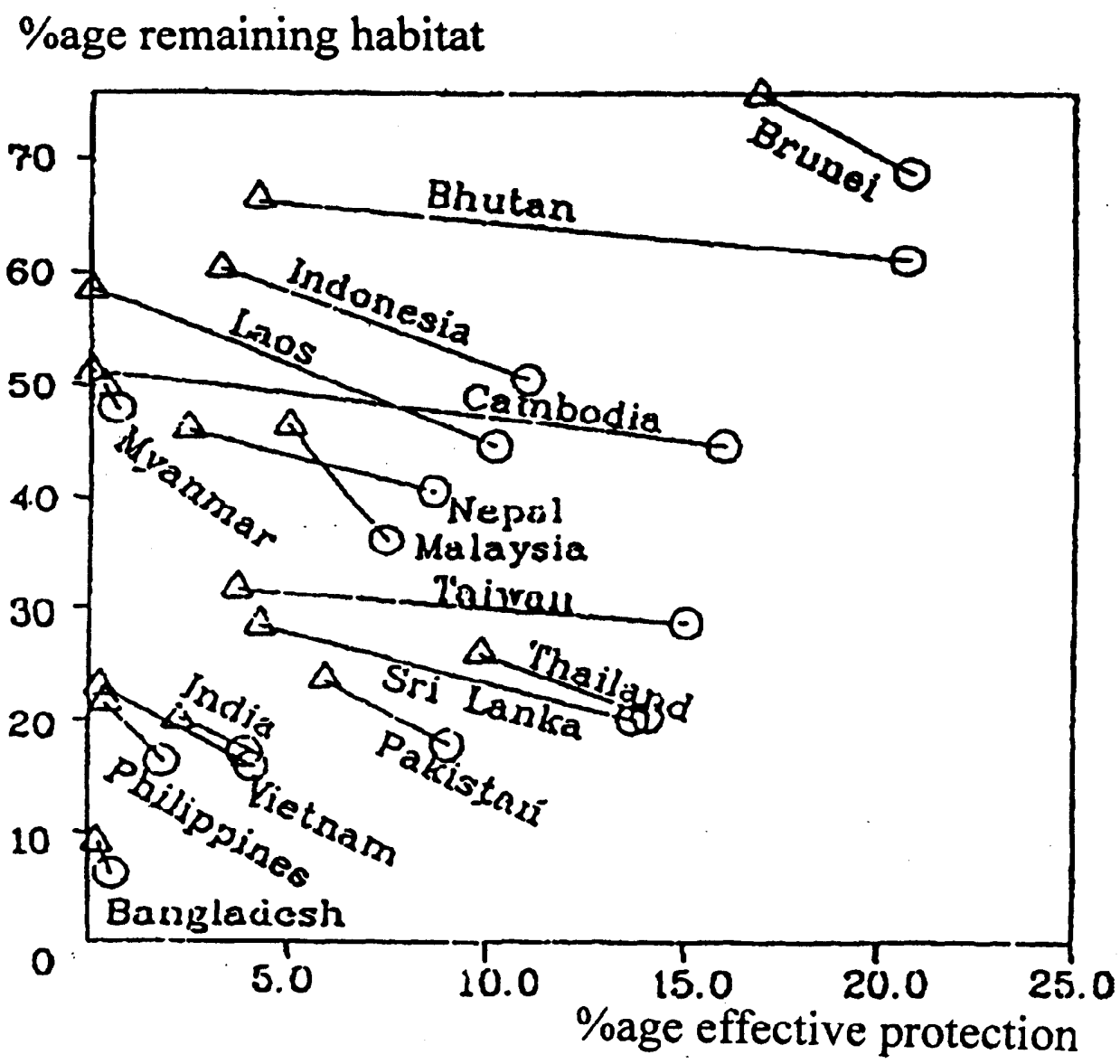

Figure 4. Changes over 10 years of Protected Areas coverage in Asia 
Figure 5 shows the impact of small incremental changes in areas conserved/destroyed on species in different conditions of forest area and species richness, based upon the slope of species area curves. When the total area of forest is small and its species richness is high a small increase in area protected will yield a large increase in the number of species protected. When the forest type is large and the diversity of species low then a similar increment in area protected will yield fewer benefits for species conservation. Conversely, the impact of forest loss will be high in the species-rich, limited-area situation, and low in the species-poor, extensiveforest situation. In more simple terms, it is far more valuable to conserve 10,000 hectares of rain forest in lowland Java or Madagascar, than a similar area in Siberia or even in Central Zaire. This may be self evident, but these trade-offs could be quantified and could help us target conservation expenditure more precisely. Such analysis could have contributed some substance to the empty political rhetoric of the Biodiversity Convention negotiations.

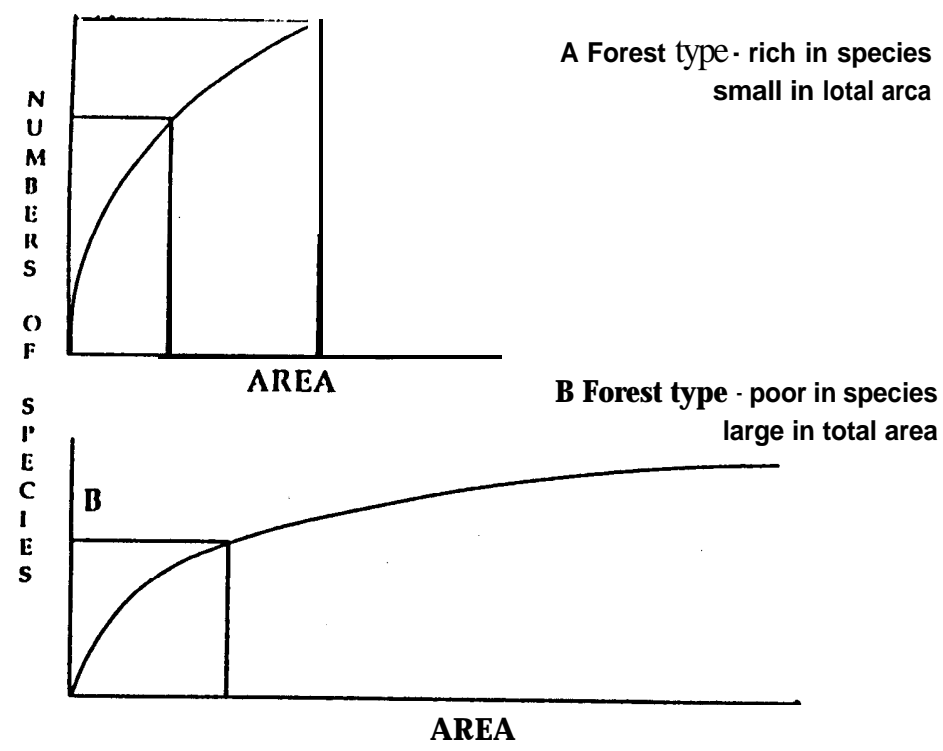

Figure 5.

Figure 6 shows the relationship between the impact of increases in expenditure on the conservation of biodiversity in forests with different levels of diversity, endemism and land demand. In general, the curve moves to the left as habitat diversity and local endemism increase. The position and slope of the curve are influenced by opportunity costs incurred through allocation of land for conservation at the expense of agriculture, etc. Lack of knowledge of species and their interactions creates uncertainties about the impact of habitat disturbance and conservation measures, and guarding against this uncertainty shifts the curve to the left. These curves demonstrate that the incremental costs of conserving all or most biodiversity in highdiversity, high-endemism, high land-pressure tropical countries, are very much greater than the costs in countries of the temperate and boreal regions where diversity and endemism is low and agricultural intensification is reducing the costs of taking land out of agriculture. In simple terms this means that tropical countries would go bankrupt if they tried apply the principles of the U.S. Endangered Species Act or similar legislation of several European countries. Attempting to protect all species in most tropical countries would cripple the development efforts of these countries. Conservation programs have to be set in this context of what is reasonable and affordable.

The critical issue for nature conservation is to target conservation expenditure to measures and sites that will impact on the steep parts of these curves. Sites must be located to capture the greatest increment in biodiversity and 


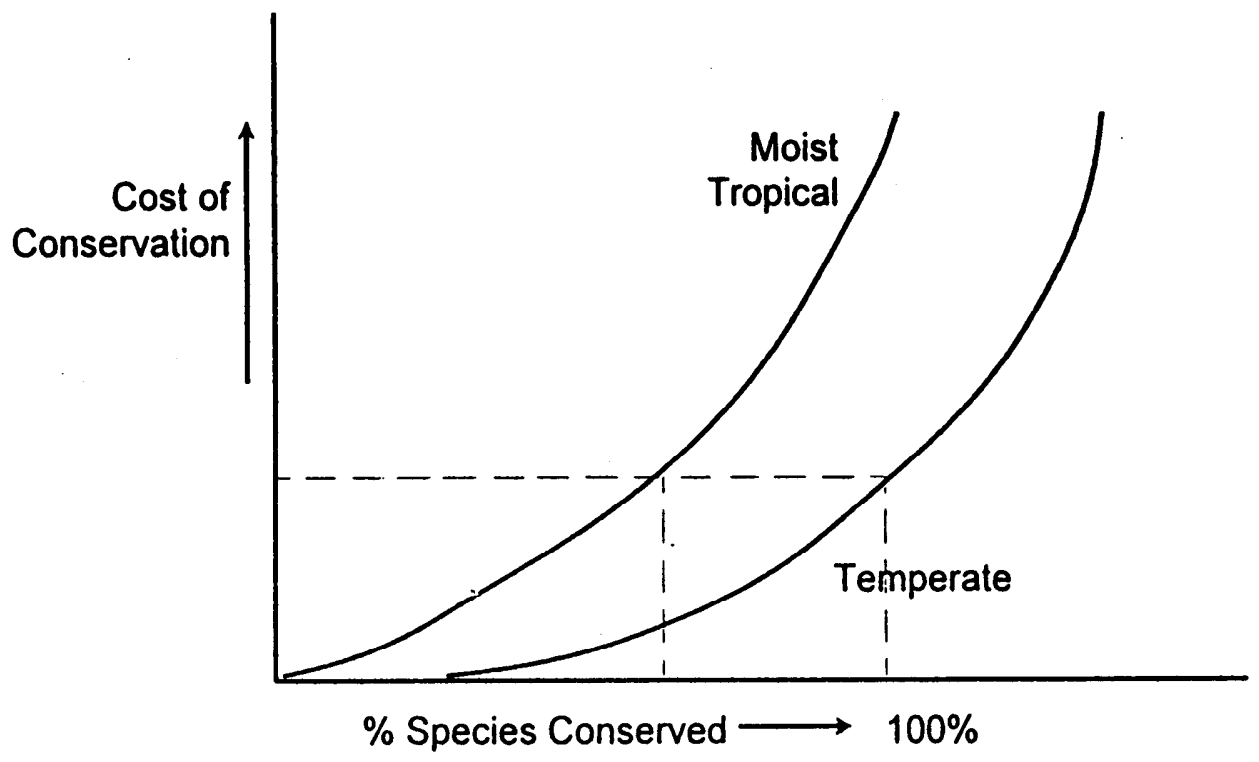

Figure 6. Incremental cost including opportunity cost of conserving species in forests with different degree of local endemism heterogeneity of habitat and human population density.

investments must yield the greatest value for money. For instance, a small investment in improving logging practice to reduce the impact on biodiversity might yield much greater benefits than an equivalent investment in trying to acquire a new totally protected site.

This leads us directly to two highly researchable issues that could make a real contribution to our ability to achieve cost effectiveness in biodiversity conservation. Both of these issues are already being investigated by researchers associated with the Prince Bernhard Chair. The tirst is the extent to which various sorts of modified forests contribute to biodiversity conservation, and the second is the impact of size and degree of isolation of forest fragments on the value of these fragments for conservation of species. (Whitmore and Sayer 1992).

The hypothesis underlying this research is that many of the arguments for establishing very large totally protected reserves in the humid tropics are based on false assumptions. Very large reserves are needed principally for those species that exist at low population densities and forage over wide areas. Many of these species are large mobile vertebrates which can move between forest fragments or subsist in modified forests. The majority of moist forest species exist at high densities and are not mobile, hence the high level of local endemism in tropical forests. The best strategy for capturing the greatest possible number of these species will be in more, but smaller, strategically located reserves. Studies now being undertaken by researchers sponsored by the Prince Bernhard Chair will examine species conservation in medium-sized forest fragments and the impact of various sorts of disturbance on forest biodiversity. This research could yield results that would make nature conservation programs much more costeffective.

\section{A Vision of Forests for the 21st Century}

Present-day conservation programs are rooted in the premise that as population increases and human demands on land and natural resources grow, there will be ever increasing pressures on natural areas. There is considerable evidence that this is not the case. In reality, as economies and populations grow, there is an increasing incentive to use resources more efficiently. This leads to improved productivity per unit area in agriculture and forestry. This, coupled with the 
higher value people attach to natural areas for ecological services and recreation, can lead to diminished pressures on, and expansion of, areas of natural habitats. At the turn of the century the island of Java had very large areas of degraded Imperata cylindrica grasslands. Today most of these areas are covered with forest gardens managed for timber, fruits, spices and other products. These forest gardens fulfil many of the ecological functions of natural forests and support far more biodiversity than the degraded lands that they replaced. The forest cover of China has increased from $9 \%$ to $14 \%$ in recent decades; and the increase has occurred in the densely populated south, not the sparsely settled north. Recent studies in Kenya (Tiffen 1993,
Tiffen et al 1993, Tiffen and Mortimore 1992), Nepal (Carter and Gilmour 1989) and Guinea (Fairhead 1993) show similar trends towards increased forest cover as population density increases and agriculture becomes more efficient.

Figure 7 shows the impact of increased productivity on the area of land needed to produce a given volume of timber. It shows that the potential for relieving pressure on natural forests is quite dramatic. Using technologies already available we could produce the world's timber needs on a tiny faction of the world's present forest land. Similar productivity increases are occurring in many of the commodities produced on tropical forest lands.

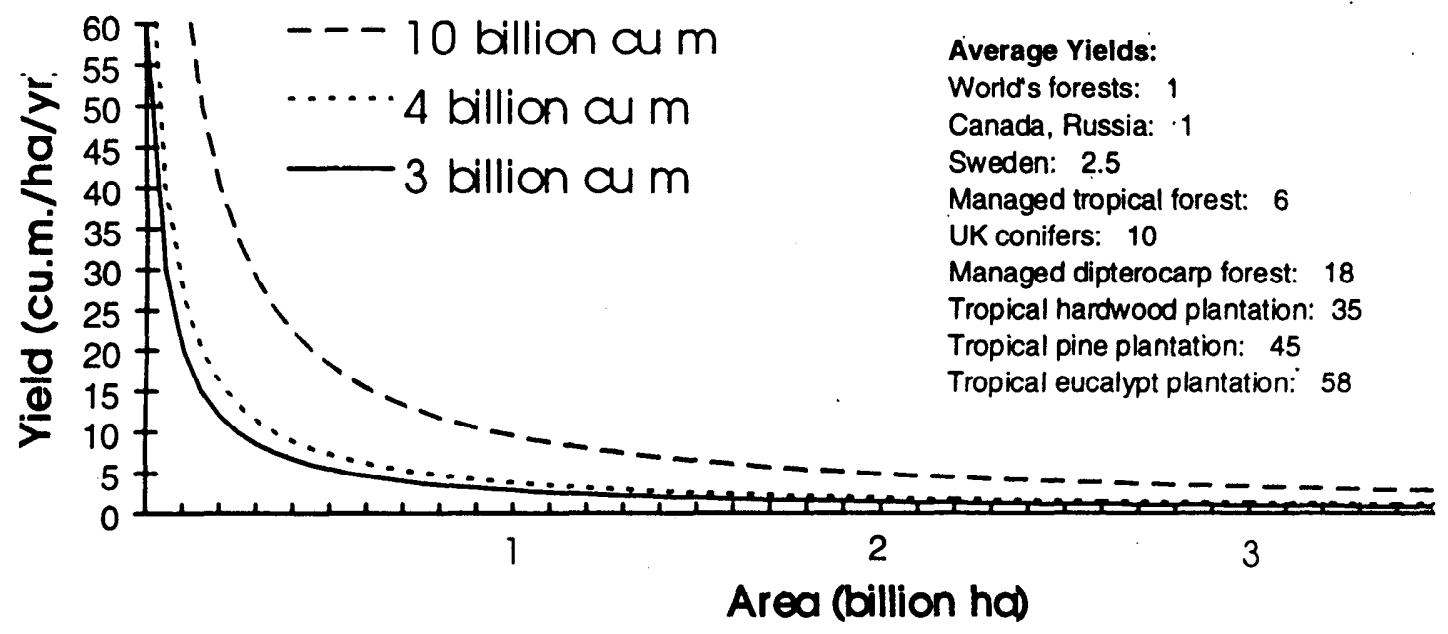

Figure 7. Impact of Productivity increases on area required to produce the World's Timber Supply.

This graph illustrates the area that would be required to produce specified quantities of timer for each 'evel of productivity. The average annual timber productivity of natural forests, worldwide, is currently $، \mathrm{~m}^{3} / \mathrm{ha} / \mathrm{yr}$, thus 4 billion ha presently yield 4 billion $\mathrm{m}^{3}$ of logs. At the other extreme, only $1 \mathrm{million}$ ha of tropical plantations could generate the same timber harvest. By increasing the productivity of forest management, the area required to preduce the same timber yield can be significantly reduced.

Source: Paper presented by D. Poore to Science, Forests and Sustainability - A Policy Dialogue. CIFOR and the Government of Indonesia, December 1994. 
It is politically correct to end presentations such as this on an optimistic note. I think that there is a cause for real but cautious optimism for tropical forests. The underlying social and economic trends in the developing tropics, especially in Asia and South America, should lead us to a situation where the task of conserving a reasonable representative sample of forest biodiversity should get easier. It may be one or two more decades before these trends become manifest. Already in countries like Costa Rica, Thailand, Malaysia and China forest areas are stable or increasing. In other countries we will lose much more forest before economic and social forces will lead to stability and forest extension. Scientific nature conservation can help understand these social and economic phenomena and relate them to our knowledge of the ecology of natural systems. It can allow us to move away from the defensive "back-to-thewall", rearguard action type of conservation towards a much more targeted, cost-effective set of programs with clear objectives and goals. To push this agenda forward we need a new generation of practitioners of scientific nature conservation. I personally would hope that the Prince Bernhard Chair at the University of Utrecht could make important contributions to this sort of work. I believe that this is the role that His Royal Highness would wish us to play and I look forward to making a small contribution to these efforts over the next few years.

Acknowledgements: My thanks to Duncan Poore for Figures 5 and 7 which are taken from an unpublished paper presented at a Meeting on Forest Policy in Indonesia in 1994.

\section{References}

Carter, A.S., and Gilmour D.A., 1989, Increase in Tree Cover on Private Farm Land in Central Nepal. Mountain Research and Development Vo1 9. No 4: 381-391.

Cassells, D.S., Bonell, M., Hamilton, L.S., Gilmour, D.A., 1987, The protective role of tropical forests: a state-of-knowledge review. In: N.T. Vergara and N.D. Briones (ed.) Agroforestry in the Humid Tropics: Its Protective and Ameliorative Roles to Enhance Productivity and Sustainability. Environment and Policy Institute, East-West Center, Honolulu, Hawaii, pp. 3 I-58.

Enters, T. (in press). The Economics of land degradation and resource conservation in Northern Thailand: Challenging the assumptions. In: Jonathan Rigg (ed.) Counting the Costs: Economic Growth and Environmental Change. Institute of Southeast Asian Studies, Singapore. Chapter 5.

Hamilton, L.S., 1986, Towards clarifying the appropriate mandate in forestry for watershed rehabilitation and management. Reprint No. 94, East-West Environment and Policy Institute, Reprinted from: Strategies, Approaches and Systems in Integrated Watershed Management. Food and Agriculture Organisation of the United Nations, Rome pp. 32-51.

Leach, M., and Fairhead, J., 1993, Whose social forestry and why? People, trees and managed continuity in Guinea's forest-savanah mosaic. Zeitschriftfur Wirtschaftsgeographie 372, pp 86-101.

Mintzberg, H., 1994, The Rise and Fail of Strategic Planning. The Free Press, New York. Maxwell Macmillan Canada, Inc., Ontario.

Sayer, J.A., 199 1, Rainforest Buffer Zones: Guidelines for Protected Area Managers. International Union for Conservation of Nature and Natural Resources, Gland.

Tiffen, M. and Mortimore, M., 1992, Environment, Population Growth and Productivity in Kenya: a case study of Machakos District. Development Policy Review 10: 359-387.

Tiffen, M., 1993, Productivity and Environmental Conservation under Rapid Population Growth: a case study of Machakos District. Journal of International Development 5,2: 207-223.

Tiffen, M., Mortimore, M. and Gichuki, F.N., 1993, More People, Less Erosion: Environmental Recovery in Kenya. John Wiley and Sons, Chichester, New York, Brisbane, Toronto, Singapore.

Wells, M. and Brandon, K., 1992, People and Parks: Linking Protected Area Management with Local Communities. The International Bank for Reconstruction and Development/The World Bank, Washington, D.C.

Whitmore, T.C. and Sayer, J.A., 1992, Tropical Deforestation and Species Extinction. Chapman Hall, London. 